\title{
大型レーザーによる実験室宇宙物理：レーザー宇宙物理
}

\author{
坂和 洋一 \\ 大阪大学 レーザーエネルギー学研究センター（テ565-0871 大阪府吹田市山田丘2-6)
}

\section{Laboratory Astrophysics with Large-Scale Lasers: Laser Astrophysics}

\author{
Youichi SAKAWA \\ Institute of Laser Engineering, Osaka University, 2-6 Yamadaoka, Suita, Osaka 565-0871
}

(Received June 13, 2016)

\begin{abstract}
Utilizing high-temperature, high-density, high-flow-velocity, and high-pressure states observed in the Universe, by large-scale lasers in the laboratories, we aim at understanding plasma physics, astrophysics, and high-density/high-pressure physics. In this article, recent progress on laser plasma astrophysics and laser earth/planetary physics, and future perspective are presented.
\end{abstract}

Key Words: Laboratory astrophysics, Laser astrophysics, Plasma astrophysics, Earth/planetary physics

\section{1. はじめに}

宇宙物理学とは, 宇宙の諸現象について得られた観測 結果を, 現代物理学の理論と研究方法を駆使して分析 し, 得られた結果に対し理論的な説明や解釈を与えるこ とを試みる学問である ${ }^{1)}$ 。我々は, 実験室で, 宇宙の興 味深い現象を実験的に研究する,「実験室宇宙物理 (Laboratory Astrophysics)」の研究を進めている.

2012年にSavin等によって出された実験室宇宙物理の レビュー論文では2)，“US National Research Council Astro 2010 Survey on Astronomy and Astrophysics”に従い3), 宇 宙物理をPlanetary systems and star formation, Stars and stellar evolution, The galactic neighborhood, Galaxies across time, Cosmology and fundamental physicsの5つのカ テゴリーに分類している. Savin等はこれら5カテゴリー を, さらにatomic, molecular, condensed matter, plasma, nuclear, particle physicsの6つの物理分野に分類し, それ ぞれの物理分野での実験室宇宙物理の成果をまとめてい $b^{2)}$.

本特集では，特に，大型レーザーを用いた実験室宇宙 物理を取り上げる。本来なら, 上記の分類に従って記述 すべきなのかもしれない，しかしここでは，我々なりの 分類で, カテゴリーの範囲を広めたレーザーを用いた実 験室宇宙物理,「レーザー宇宙物理 (Laser Astrophysics)」 についてまとめる。

レーザー宇宙物理において実験対象とする分野は，天 文学 (Astronomy) · 天体物理 (Astrophysics), 宇宙空間物 理(Space Physics), 地球·惑星物理 (Earth/Planetary Physics) が挙げられる。天文学・天体物理は, 恒星・銀河・星間
物質などの天体の物理的性質や天体間の相互作用などを 研究対象としている，宇宙空間物理は，地球近傍の宇宙 空間における物理現象を研究する学問分野であり，電離 圈, 磁気圈, 磁気圈外の太陽風が流れる領域である惑星 間空間，などを研究対象とする。地球・惑星物理は，太 陽系の形成·進化, 地球の進化, 地球内部の物理, 惑星 の進化に重要な衝突・破壊などの基礎物理を研究してい る.

以下に，天文学・天体物理と宇宙空間物理の共通の テーマとして無衝突衝撃波を例にとって, レーザー宇宙 物理の特徵を述べる。

天文学・天体物理の分野で対象となる無衝突衝撃波と して, 超新星残骸 (supernova remnants: SNR), 銀河団, 活動銀河核， $\gamma$ 線バースト，等における衝撃波がある. これらの無衝突衝撃波は, 高エネルギー粒子である宇宙 線のうち, ほほ $10^{8} \mathrm{eV} ら 10^{20} \mathrm{eV}$ の領域で, 約 -2 のべ キ乗エネルギースペクトルを持つ, 太陽系外宇宙線の起 源と考えられており，電磁波によるイメージング・スペ クトル観測を中心とした研究が行われている。例えば, 光子エネルギーが $10^{-6} \mathrm{eV}$ 電波から $10^{4} \mathrm{eV}$ の線領域には, 電子のシンクロトロン放射が観測される。 $10^{9} \mathrm{eV}(\mathrm{GeV})$

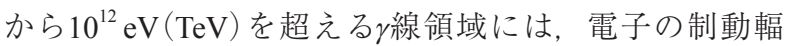
射がある。また，宇宙マイクロ波背景放射や星からの可 視・赤外光といった低エネルギー光子が, 電子の逆コン プトン放射として観測される。さらに，宇宙線核子が星 間ガス中の陽子との衝突によって生成される, 中性パイ 中間子 $\pi^{0}$ の崩壊によって放出される $\gamma$ 線等も観測され る。これら電磁波のスペクトルを詳細に計測することに よって, 放射機構を同定し, 多くの情報を得ることが出 
来る，例えば，SNRからのシンクロトロン放射によって，

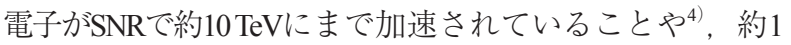
年周期の放射強度の時間変化から, SNRにおいて典型的 な星間磁場である3-10 $\mu \mathrm{G}$ から約100倍の磁場増幅が行 われていることが示された

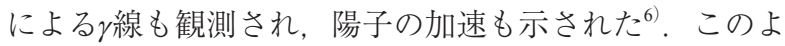
うに, 天文学・天体物理では, 電磁波観測によって衝撃 波のグローバルな情報を得ることができる。しかし，十 分な空間分解能を持ったローカルな計測は困難である.

宇宙空間物理では, 地球バウショックや太陽圈 (太陽 風) 終端衝撃波, 等の無衝突衝撃波が研究されており, 後者は約 $10^{7}-10^{8} \mathrm{eV}$, 太陽近傍とは異なる化学組成を 示す宇宙線異常成分の起源と考えられている7 ${ }^{7)}$. 太陽圈 では，観測衛星を打ち上げ，プラズマ分布関数や電場・ 磁場, 波動等の詳細なその場計測が行われている。この ように, 宇宙空間物理研究では, 無衝突衝撃波のローカ ルな計測が可能である。しかし, 衝撃波のグローバルな 情報は得ることができず，全体像をイメージすることは 困難である。

レーザー宇宙物理では，天文学・天体物理と宇宙空間 物理で研究されている, 例えば無衝突衝撃波のような興 味深い物理現象を，レーザーを用いて実験室で時間・空 間的にスケールダウンして検証する。初期条件や各種パ ラメー夕を変化させ, 現象発生時からの時間発展を, 受 動的・能動的な様々な計測器を用いて, ローカルとグ ローバルな情報, ミクロとマクロな物理量を同時に得る ことができる.

また，地球・惑星物理研究では，レーザーを用いるこ とによって, 惑星中心部に相当する高圧状態や, 小天体 が惑星に衝突したと考えられている高速度の飛翔体加速 を実験室で実現することが可能となり，精力的に実験が 行われるようになった。

\section{2.レーザー宇宙物理のあゆみ}

レーザーは1960年に発明された。そのわずか 4 年後に， Dawsonはレーザーを用いた無衝突衝撃波やバウショッ ク生成等の宇宙物理実験の可能性を提案している ${ }^{8)}$. 1980年代前半に, 米国, 英国, 日本, フランスで相次い でnsパルスのTWレーザーが建設された。これらのレー ザーを用いて，1980年代後半から1990年代にかけて， SNR衝撃波や地球のバウショックを模擬した外部磁場中 の無衝突衝撃波実験 ${ }^{9}{ }^{9}$, 爆風波の不安定性実験 ${ }^{10)}$, Rayleigh-TaylorやRichtmyer-Meshkov不安定性の実験 ${ }^{11,12)}$, 等が行われた。

1996年には米国ローレンス・リバモア研究所で, 第1 回の高エネルギー密度実験室宇宙物理国際会議（International Conference of High-Energy-Density Laboratory Astrophysics: HEDLA)が開催されるに至った。

1999年には, 高出力レーザーを用いた宇宙物理研究に 関する論文が相次いで発表され, 超新星爆発の流体不安 定性, 高強度レーザーを用いた電子・陽電子生成とFireballの模擬実験, 巨大惑星内部の状態方程式, 等が議
論・提案された ${ }^{13-16)}$

我が国では世界にさきがけて，超新星SN1987Aの爆発 における流体不安定性に関連して，1993年に宇宙模擬実 験の可能性が示唆され ${ }^{17)}, 1998$ 年には輻射流体力学, 非 平衡原子過程, 衝撃波・流体不安定性, 電磁流体プラズ マ, リコネクション，相対論的プラズマ，等が宇宙と レーザー・プラズマの観点から検討されている ${ }^{18)}$.

このように，我が国ではいち早く，高出力レーザーを 用いた宇宙物理実験の提案がなされていたが，本格的に 実験が行われるようになったのは，2006年に阪大レー ザー研が全国共同利用施設化してからになる。

以下に, レーザー宇宙物理を, レーザー宇宙プラズマ 物理 (3節) とレーザー地球・惑星物理 (4節)に分けて，そ れぞれの進展をまとめる。

\section{3. レーザー宇宙プラズマ物理の進展}

\section{1 無衝突衝撃波の生成}

無衝突衝撃波とは, 荷電粒子間のクーロン衝突の平均 自由行程よりも，はるかに短い領域で生成される衝撃波 である。その散逸過程は, 粒子間衝突ではなく, プラズ マの集団現象によって生成される, 電場や磁場と荷電粒 子との相互作用によるものである。1節で示した宇宙で 観測される衝撃波は，ほとんどが無衝突衝撃波であり， 宇宙線の生成に重要な役割を果たすと考えられている。

我々は，高出力レーザーを用いてこれら衝撃波の生成 機構や物理を研究している。本特集では, 坂和によって 詳しい解説がなされている19).

\section{2 磁場生成·増幅}

宇宙には，いたるところに磁場が存在している。磁場 の存在しない初期の宇宙から，どのようにして磁場が生 成されたのか，またどのようにして磁場が増幅されて， 現在観測されている值に達したのかを明らかにすること は，宇宙物理の大きな課題である.

\subsection{1 磁場生成}

Kulsrund等は, 数值計算で, プラズマ密度と温度の勾 配のずれによるバロクリニック効果 (Biermann battery効 果)によって約 $10^{-21} \mathrm{G}$ の原始銀河の種磁場が生成される ことを示した ${ }^{20)}$ 。我々はレーザー実験で，無磁場中で生 成された衝撃波において，Biermann battery効果によって 磁場が生成され，相似関係を用いることによって，この 過程で原始銀河の種磁場生成が可能であることを示し た ${ }^{21)}$ 。実験では, 数mbarのへリウムガス雲囲気中で数 $100 \mathrm{~J}$ のレーザー(527 nm, $1.5 \mathrm{~ns})$ をカーボンロッドター ゲットに照射し，衝撃波 (Sedov-Taylorブラスト波)を励 起した (Fig. 1(a))。数100 nsまでの衝撃波の時間発展を， 干渉計測および可視自発光計測で観測し，その結果を， 輻射流体シミュレーションを用いて, 磁気プローブが設 置された場所(ターゲットから約 $30 \mathrm{~mm}$ ) と時間 (約 $1 \mu \mathrm{s})$ に おけるプラズマ密度，温度の情報に外挿した。 Fig. 1(b) に示す磁気プローブで得られた磁場の值 $($ 約 $20 \mathrm{G})$ を，ス 

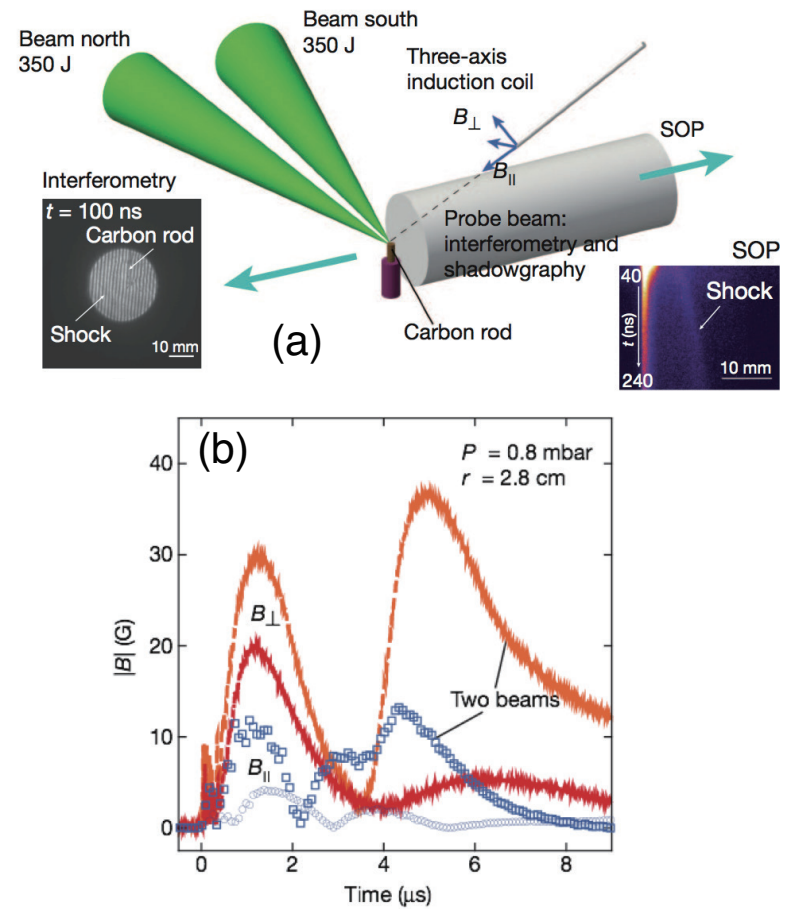

Fig. 1 (a) Experimental setup showing the laser beams and diagnostics configuration. The inset on the left shows an example of an interferometric (IF) image. The inset on the right shows a streaked self-emission optical pyrometry (SOP) image in a narrow band centered at $450 \mathrm{~nm}$. (b) Magnetic-field measurements from induction coils. The rise and gradual decay of $B_{\perp}$ (lines) was consistent with the shock front crossing the coil and the subsequent evolution of the shocked material. ${ }^{21}$ )

ケーリング則に当てはめると, 約7億年の時間をかけて Biermann battery効果により, 約 $10^{-21} \mathrm{G}$ という原始銀河 の種磁場が生成されることを示した ${ }^{21)}$.

\subsection{2 磁場増幅}

レーザー実験で，この種磁場が乱流によって増幅され ることを示した ${ }^{22-24)}$. 磁場生成実験と同様のレーザー・ ターゲット条件で, プラズマ流を生成し, Biermann battery効果によって磁場が作られた。プラズマ流をター ゲットから10 mmの位置に設置したグリッドを透過させ ることによって, 乱流磁場を実現し, 磁気プローブに よって周波数スペクトルを測定した。 その結果，グリッ ドを挿入することによって磁場強度は約 2 倍増加し, 周 波数スペクトルは $\omega^{-11 / 3}$ となった. $\omega \sim v_{0} k$ の分散関係を 用いると，波数スペクトルは $k^{-11 / 3}$ の Golitsyn power-law を示すことになる22).

さらに，2組のレーザー，ターゲット，グリッドを用 いて対向するプラズマ乱流を生成し衝突させた場合 (Fig. 2(a)，2(b)), 乱流磁場強度はさらに2-3倍増加し

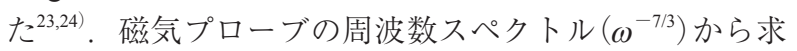
めた乱流磁場の波数スペクトルも $k^{-17 / 9}$ となり (Fig. 2(c)), 乱流化が進むにつれてスペクトルが緩やかになることが 示された ${ }^{23,24)}$.

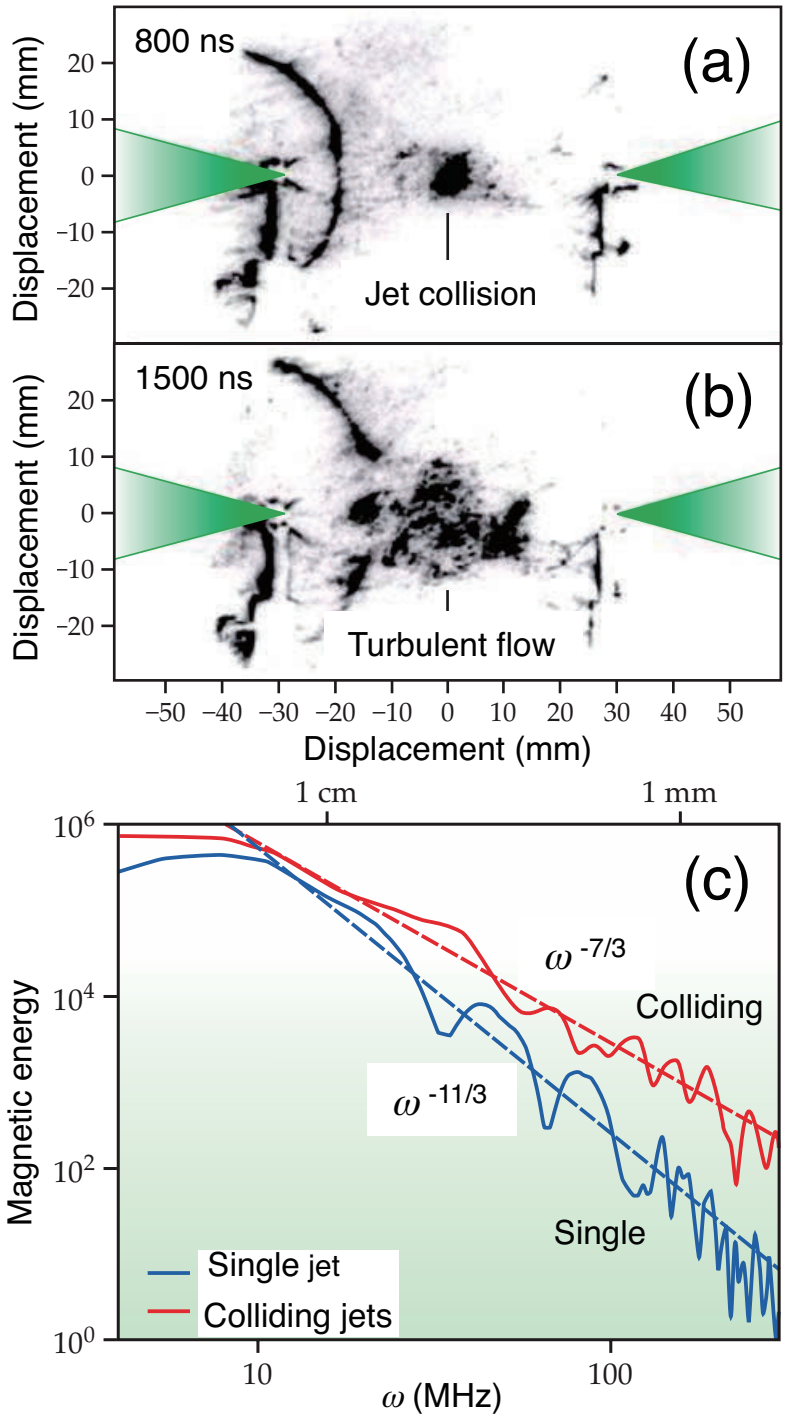

Fig. 2 (a), (b) Focused pulsed laser beams (triangles) launch a pair of plasma jets. (a) The jets collide $800 \mathrm{~ns}$ after each laser pulse, and (b) a region of turbulence develops within another $700 \mathrm{~ns}$. (c) The magnetic energy spectrum $M(\omega)=|B(\omega)|^{2}$. The slope of the spectrum in the case of colliding jets is shallower than in the case of a single jet. ${ }^{22-24)}$

\section{3 磁気リコネクション}

「太陽コロナはなぜ熱い？」.これは2016年日本物理学 会誌の「物理学70の不思議」の5番目に出てきた「不思議」 である ${ }^{25)}$ ：太陽の表面である光球や，太陽の内層大気で ある彩層に比べ，外層大気のコロナの温度が2桁以上高 い. この太陽コロナ加熱機構の1つとして磁気リコネク ションが有力視されている ${ }^{25)}$.

磁気リコネクションの室内実験は1960年代から多くの 磁場閉じ込め装置を用いて行われてきた ${ }^{26,27)}$ 。近年, 激 光XII号を含む世界の大型レーザーを用いた磁気りコネ クション実験が行われるようになり，注目されている. 本特集では, 森高氏が最新の研究動向をまとめている ${ }^{28)}$.

\section{4 電子・陽電子対生成}

活動銀河核ジェット, $\gamma$ 線バースト, X線連星等の宇 
宙における高エネルギー現象では，相対論的な電子・陽 電子プラズマが生成されていると考えられている。早く から注目されていた，高強度レーザーを用いた電子・陽 電子対生成では，2015年に，電子と陽電子の数が等しく なる電子・陽電子プラズマの生成が報告され29), 今後の 進展が期待される。

本特集では，中井氏等によって電子・陽電子対生成実 験の結果がまとめられている30).

\section{5 非コヒーレントWakefield電子加速}

約 $10^{15} \mathrm{eV}$ 超える宇宙線は，天の河銀河の外で生成さ れた，銀河系外宇宙線であると考えられている。ここで は, この銀河系外宇宙線の起源の1つとして考えられて いる, Wakefield加速に関する研究結果を示す.

Wakefield加速のPICシミュレーションの結果, 規格化 されたレーザー強度 $a_{0}$ が相対論的な領域 $\left(a_{0}>1\right)$ で, な おかつレーザーパルスの空間的スケール $\left(w_{0}:\right.$ レーザー スポット径 $)$ が電子のスキン長 $\left(c / \omega_{\mathrm{pe}}, c\right.$ は光速, $\omega_{\mathrm{pe}}$ は電 子プラズマ振動数)よりも十分に大きな領域であれば, Self-modulationとFilamentationにより，Wakefieldの後面が 非コヒーレントとなり，電子は加速と散乱によって非熱 的に加速される事が示された ${ }^{31)}$ 。 その結果, 電子エネル ギースペクトルは，レーザー強度とプラズマ密度によら ず，ほぼー2の指数を持つべキ乗の分布を示した ${ }^{311}$.

このシミュレーション結果の実験的な検証が，激光 XII号 (GXII) と激光ペタワット (PW) レーザーを用いて行 われた ${ }^{32-34)}$. Fig. 3(a) に示すように，プラスチック製の シリンダーを，6本のGXIIレーザーで爆縮することに よって，ホロー状のプラズマを生成した， $3.1 \mathrm{~ns}$ 後にPW

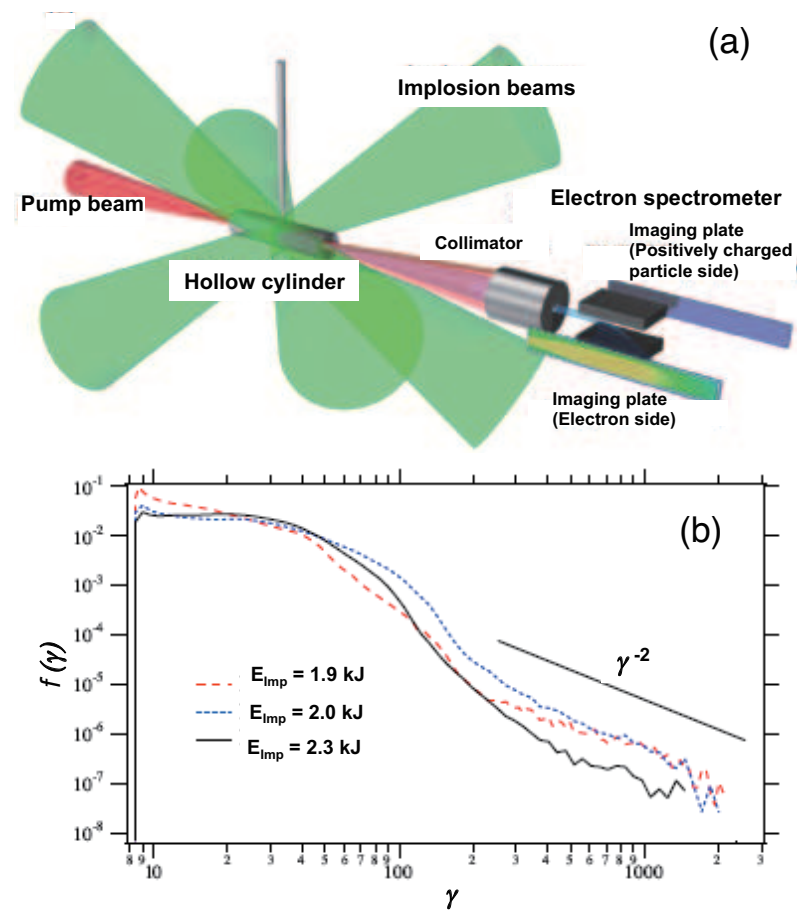

Fig. 3 (a) Schematic of the experiment. ${ }^{32-34)}$ (b) Energy distribution functions of the electrons in logarithmic scales. ${ }^{33,34)}$
のポンプレーザー $\left(4.3 \times 10^{18} \mathrm{~W} / \mathrm{cm}^{2}\right)$ を照射し， PWレー ザーの前方に設置した電子スペクトロメータ（ESM）を 用いて，電子のエネルギースペクトルを計測した。高 エネルギー成分に着目すると, Fig. 3(b) に示すように, $\gamma>200$ の領域で，爆縮レーザーのエネルギー，すなわち プラズマ密度によらず，ほぼー2の指数を持つべキ乗の エネルギースペクトルを示し，シミュレーション結果と 良く一致した ${ }^{33,34)}$ 。ここで, 実験結果から求めた無次元 パラメータは $a_{0} \equiv 1.87, w_{0} \omega_{\mathrm{pe}} / c \equiv 37-82$ となり, 非コ ヒーレントなWakefield加速の条件を満たす。

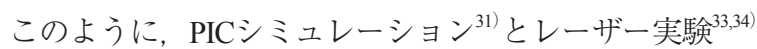
から, 非コヒーレントなWakefield加速によって, 宇宙 線と同様の，－2に近い指数を持つ，普遍的なべキ乗の 電子エネルギースペクトルが得られたことは注目に值す る.

\section{6 光電離プラズマのX線天文学}

ブラックホール $(\mathrm{BH})$ と伴星からなる連星においては, 伴星から放出された物質がBHの重力に引かれて $\mathrm{BH} の$ 周りに降着円盤を形成し, 重力エネルギーを解放して $\mathrm{keV}$ 領域のX線を放出する。これがX線連星である。

激光XII号を用いてX線連星の模擬実験が行われた ${ }^{35)}$. レーザーをプラスチック球に照射することによって，面 密度 $0.1 \mathrm{~g} / \mathrm{cm}^{2}, \quad 0.5 \mathrm{keV}$ のプランク分布を持つ爆縮プラズ マコアを生成した。この熱放射をコアから約 $1 \mathrm{~mm}$ はな れた位置に設置した低密度のケイ素プラズマ $\left(10^{20} \mathrm{~cm}^{-3}\right.$, $30 \mathrm{eV})$ に照射することによって，光電離がおこり，ケイ 素から $\mathrm{keV}$ 領域のX線が観測され，X線観測衛星から得 られたスペクトルとの比較が行われた ${ }^{35)}$.

本特集では, 藤岡氏によって詳しい解説がなされてい る $^{36)}$.

\section{4.レーザー地球・惑星物理の進展}

\section{1 惑星の内部構造探査 : 状態方程式}

太陽系の惑星は, (a) 地球型, (b) 木星型, (c) 天王 星・海王星型の3つに分類できる.

(a) 地球の核では, 固体の鉄の内核を，軽元素を含ん だ液体の鉄からなる外核が取り囲んでおり ${ }^{37)}$ ，中心部の 圧力は約 $350 \mathrm{GPa}$ と言われている ${ }^{38)}$. (b) 木星は, そのほ とんどが水素で構成されており，巨大ガス惑星と呼ばれ ている，中心部には，岩石や氷でできたコアが存在し， その周りに，主に水素からなるエンベロープと呼ばれる 外層があると考えられている ${ }^{39)}$ 。また，エンベロープの 水素は，表面付近では分子の状態で存在しているが，中 心部に近づくにつれて，200-400 GPaで圧力電離による 水素分子の金属化が起こると予想されている ${ }^{40)}$. (c) 天 王星や海王星の内部には，水，アンモニア，メタンが多 く含まれており，巨大水惑星と呼ばれている。それらが 20-600 GPaの領域で凝縮液体として存在していると考え られている41)

このように，惑星の内部構造を探るためには，鉄，水 素, 水等の数 $100 \mathrm{GPa}$ 領域での状態方程式(EOS) を理解 
することが必要不可欠となる。このような高圧力状態を 実現する方法として，レーザーによる衝撃圧縮が最も有 効な手段の 1 つである ${ }^{42)}$ 。 レーザー以外の衝撃圧縮法と して，ガス銃やZピンチも用いられている．例えば水素 の場合，2段式ガス銃で得られた圧力は，10 GPaが最高 記録である ${ }^{43)}$ ：激光XII号を用いることによって，55 GPa までのEOSが調べられた ${ }^{44)}$ 。また, 水の衝撃圧縮では, 激光XII号を用いて，260 GPaが得られている ${ }^{45)}$ 。近年 は，米国サンディア国立研究所のZピンチ装置Z-Machineを用いたEOS研究も進められている ${ }^{46)}$.

さらに，ダイアモンドアンビルセル(DAC)を用いた 静的圧縮によって, 比較的高い圧力まで予備圧縮した後 にレーザー衝撃圧縮を行うことによって, 温度上昇を格 段に抑えた高圧状態を実現できる ${ }^{47,48)}$ 。このようなDAC と衝撃圧縮の組み合わせは，レーザー実験でしか実現で きない手法である。

本特集では, 関根氏によって地球型惑星の状態方程式 に関する最新の研究結果がまとめられている ${ }^{49)}$.

\section{2 弾丸飛翔体加速実験}

惑星集積過程の末期には, 小天体が惑星に $10 \mathrm{~km} / \mathrm{s}$ 以 上の速度で衝突した, と考えられている。この高速衝突 が，惑星表層環境にどのような影響を与えたのかを，実 験室で探る試みが行われている。これまでに，2段式軽 ガス銃や静電加速器を用いた飛翔体加速実験が行われて いた。門野等は，激光XII号を用いて，0.1 mm以上のマ クロサイズ飛翔体によって, $10 \mathrm{~km} / \mathrm{s}$ 以上の衝突速度を もつ弾丸飛翔体加速実験を行い, 衝突蒸気の分光測定 · 質量分析, 衝突クレーターのスケーリング則の導出, 放 出破片回収実験，等を行っている ${ }^{50,51)}$.

本特集では，大野氏 ${ }^{52)}$ と境家氏 ${ }^{53)}$ 等によって詳しい解 説がなされている.

\section{5. 今後の展望}

本稿では, レーザー宇宙物理研究の特徴や歴史, レー ザー宇宙プラズマ物理とレーザー地球・惑星物理の進展 をまとめた。

今後の展望として, nsレーザーを用いた実験では, これ

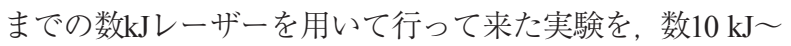
数MJの大型レーザー (Omega, NIF, LMJ)を用いること により，より宇宙現象に近いパラメータでの実験や，こ れまでに実現できなかった現象をとらえることができる 可能性がある。また，レーザーをコイル型ターゲットに 照射することにより(本特集で藤岡氏によって解説され ている $)^{36)}, 10 \mathrm{MG}(\mathrm{kT})$ 級の磁場生成が可能となった ${ }^{54-56)}$. この超高強度磁場を用いることによる, これまで得られ なかった新たなパラメー夕領域での宇宙物理実験が注目 される。また，高エネルギーnsレーザーを用いた実験で は，高強度ps，fsレーザーを用いたX線バックライトや プロトンバックライトによる, 密度 ·電場・磁場等の詳 細な計測が必要不可欠になりつつある.

fsレーザーでは現在, 世界各国でPW級レーザーが稼
働しており，さらに，10 PWレーザーの建設が進められ ている。 今後は, psやfsパルスレーザーを用いた相対論 的プラズマ物理研究が注目されると思われる ${ }^{57)}$. 理化学 研究所のX線自由電子レーザー(XFEL) SACLAでは, XFELと同時照射が可能な2台のfsレーザー (500 TW)が, 2016年度に稼働予定である。 fsレーザー生成プラズマの XFELによるプローブ計測によって，今後，相対論的プ ラズマ物理の詳細が明らかになる可能性がある.

最後に，レーザー研は2016年度からも共同利用・共同 研究拠点活動を継続して行う事になった。レーザー宇宙 物理研究がますます発展して行く事を目指して, これか らも共同研究を推進していく.

\section{謝 辞}

本稿をまとめるにあたって，議論していただいた佐野 孝好氏に感謝します。

\section{参考文献}

1) 桜井邦朋：宇宙物理学(共立出版, 2006).

2) D. W. Savin, N. S. Brickhouse, J. J. Cowan, R. P. Drake, S. R. Federman, G. J. Ferland, A. Frank, M. S. Gudipati, W. C. Haxton, E. Herbst, et al.: Rep. Prog. Phys. 75 (2012) 036901.

3) National Research Council: New Worlds, New Horizons in Astronomy and Astrophysics (National Academies Press, 2010).

4) G. Cassam-Chenai, J. P. Hughes, E. M. Reynoso, C. Badenes, and D. Moffett: Astrophys. J. 680 (2008) 1180.

5) Y. Uchiyama, F. A. Aharonian, T. Tanaka, T. Takahashi, and Y. Maeda: Nature 449 (2007) 576.

6) M. Ackermann, M. Ajello, A. Allafort, L. Baldini, J. Ballet, G. Barbiellini, M. G. Baring, D. Bastieri, K. Bechtol, R. Bellazzini, et al: : Science 339 (2013) 807.

7) M. E. Pesses, D. Eichler, and J. R. Jokippi: Astrophys. J. 246 (1981) L85.

8) J. M. Dawson: Phys. Fluids 7 (1964) 987.

9) A. R. Bell, P. Choi, A.E. Dangor, O. Willi, D. A. Bassett, and C. J. Hooker: Phys. Rev. A 38 (1988) 1363.

10) J. Grun, J. Stamper, C. Manka, J. Resnick, R. Burris, J. Crawford, and B. Ripin: Phys. Rev. Lett. 66 (1991) 2738.

11) B. A. Remington, S. V. Weber, M. M. Marinak, S. W. Haan, J. D. Kilkenny, R. J. Wallace, and G. Dimonte: Phys. Plasmas 2 (1995) 241

12) B. A. Remington, J. Kane, R. P. Drake, S. G. Glendinning, K. Estabrook, R. London, J. Castor, R. J. Wallace, D. Arnett, E. Liang, et al:: Phys. Plasmas 4 (1997) 1994.

13) B. A. Remington, D. Arnett, R. P. Drake, and H. Takabe: Science 284 (1999) 1488.

14) R. P. Drake: J. Geophys. Res. A 7 (1999) 14505.

15) D. Ryutov, R. P. Drake, J. Kane, E. Liang, B. A. Remington, and W. M. Wood: Astrophys. J. 518 (1999) 821.

16) H. Takabe, H. Nagatomo, A. Sunahara, N. Ohnishi, A. I. Mahdy, Y. Yoda, S. Naruo, H. Azechi, H. Nishimura, and K. Mima: Plasma Phys. Cont. Fusion A 41 (1999) 75.

17）高部 英明：プラズマ・核融合学会誌 69（1993）1285.

18）高部英明：プラズマ・核融合学会誌 74 (1998) 1254 .

19) 坂和 洋一：レーザー研究 44 (2016) 583.

20) R. M. Kulsrud, R. Cen, J. P. Ostriker, and D. Ryu: Astrophys. J. 480 (1997) 481

21) G. Gregori, A. Ravasio, C. D. Murphy, K. Schaar, A. Baird, A. R. Bell, A. Benuzzi-Mounaix, R. Bingham, C. Constantin, R. P. Drake, et al: Nature 481 (2012) 480.

22) J. Meinecke, H. W. Doyle, F. Miniati, A. R. Bell, R. Bingham, R. Crowston, R. P. Drake, M. Fatenejad, M. Koenig, Y. Kuramitsu, et al.: Nature Phys. 10 (2014) 520.

23) J. Meinecke, P. Tzeferacos, A. Bell, R. Bingham, R. Clarke, E. 
Churazov, R. Crowston, H. Doyle, R. P. Drake, R. Heathcote, et al.: PNAS 112 (2015) 8211.

24) J. Miller: Phys. Today 68, No. 9 (2015) 16.

25) 会誌編集委員会: 日本物理学会誌 71 (2016) 209.

26) E. G. Zweibel and M. Yamada: Annu. Rev. Astron. Astrophys. 47 (2009) 291.

27) M. Yamada, R. Kulsrud, and H. Ji: Rev. Mod. Phys. 82 (2010) 603.

28) 森高外征雄：レーザー研究 44 (2016) 602

29) G. Sarri, K. Poder, J. M. Cole, W. Schumaker, A. Di Piazza, B. Reville, T. Dzelzainis, D. Doria, L. A. Gizzi, G. Grittani, et al.: Nature Commun. 6 (2015) 6747.

30) 中井光男, 有川 安信, 西村 博明, and Hui Chen：レーザー 研究 44 (2016) 595.

31) Y. Kuramitsu, Y. Sakawa, T. Kato, H. Takabe, and M. Hoshino: Astrophys. J. Lett. 682 (2008) L113.

32) N. Nakanii, K. Kondo, Y. Kuramitsu, Y. Mori, E. Miura, K. Tsuji, K. Kimura, S. Fukumochi, M. Kashihara, T. Tanimoto, et al.: Appl. Phys. Lett. 93 (2008) 081501.

33) Y. Kuramitsu, N. Nakanii, K. Kondo, Y. Sakawa, Y. Mori, E. Miura, K. Tsuji, K. Kimura, S. Fukumochi, M. Kashihara, et al.: Phys. Rev. E 83 (2011) 026401.

34) Y. Kuramitsu, N. Nakanii, K. Kondo, Y. Sakawa, Y. Mori, E. Miura, K. Tsuji, K. Kimura, S. Fukumochi, M. Kashihara, et al.: Phys. Plasmas 18 (2011) 010701.

35) S. Fujioka, H. Takabe, N. Yamamoto, D. Salzmann, F. Wang, H. Nishimura, Y. Li, Q. Dong, S. Wang, Y. Zhang, et al.: Nature Phys. 5 (2009) 821.

36）藤岡 慎介：レーザー研究 44 (2016) 589.

37) F. Birch: J. Geophys. Res. 57 (1952) 227.

38) D. Alfe, M. J. Gillan, and G. D. Price: Nature 401 (1999) 462.

39) T. Guillot, D. J. Stevenson, W. B. Hubbard, D. Saumon: in Jupiter: The Planet, Satellites and Magnetosphere, eds. F. Bagenal, T. E. Dowling, W. B. McKinnon (Cambridge University Press, Cambridge, 2004) p. 35.

40) N. Nettelmann, B. Holst, A. Kietzmann, M. French, R. Redmer, and D. Blaschke: Astrophys. J. 683 (2008) 1217.

41) W. B. Hubbard: Science 214 (1981) 9.

42) G. W. Collins, L. B. da Silva, P. Celliers, D. M. Gold, M. E.
Foord, R.J. Wallace, A. Ng, S. V. Weber, K. S. Budil, and R. Cauble: Science 281 (1998) 1178.

43) W. J. Nellis, A. C. Mitchell, M. van Thiel, G. J. Devine, R. J. Trainor, and N. Brown: J. Chem. Phys. 79 (1983) 1480.

44) T. Sano, N. Ozaki, T. Sakaiya, K. Shigemori, M. Ikoma, T. Kimura, K. Miyanishi, T. Endo, A. Shiroshita, H. Takahashi, et al.: Phys. Rev. B 83 (2011) 054117.

45) T. Kimura, N. Ozaki, T. Sano, T. Okuchi, K. Shimizu, K. Miyanishi, T. Terai, T. Kakeshita, Y. Sakawa, and R. Kodama: J. Chem. Phys. 142 (2015) 164504.

46) M. D. Knudson, M. P. Desjarlais, R. W. Lemke, T. R. Mattsson, M. French, N. Nettelmann, and R. Redmer: Phys. Rev. Lett. 108 (2012) 091102.

47) P. Loubeyre, P. M. Celliers, D. G. Hicks, E. Henry, A. Dewaele, J. Pasley, J. Eggert, M. Koenig, F. Occelli, K. M. Lee, et al.: High Pressure Research 24 (2004) 25.

48) J. Eggert, S. Brygoo, P. Loubeyre, R. S. McWilliams, P. M. Celliers, D. G. Hicks, T. R. Boehly, R. Jeanloz, and G. W. Collins: Phys. Rev. Lett. 100 (2008) 124503.

49）関根 利守：レーザー研究 44 (2016) 617.

50）門野敏彦, 重森啓介, 境家達弘, 弘中陽一郎, 佐野 孝好, 大谷一人，藤原 隆史，持山智浩，藤岡 慎介，黑澤 耕介， 他：日本惑星科学会誌 18 (2009) 4.

51) T. Kadono, T. Sakaiya, Y. Hironaka, K. Otani, T. Sano, T. Fujiwara, T. Mochiyama, K. Kurosawa, S. Sugita, Y. Sekine, et al.: J. Geopys. Res. 115 (2010) E04003.

52) 大野宗祐：レーザー研究 44 (2016) 608 .

53) 境家達弘, 門野 敏彦, 近藤忠：レーザー研究 44 (2016) 613.

54) S. Fujioka, Z. Zhang, K. Ishihara, K. Shigemori, Y. Hironaka, T. Johzaki, A. Sunahara, N. Yamamoto, H. Nakashima, et al.: Sci. Reports 3 (2013) 1170.

55) J. J. Santos, M. Bailly-Grandvaux, L. Giuffrida, P. Forestier-Colleoni, S. Fujioka, Z. Zhang, P. Korneev, R. Bouillaud, S. Dorard, D. Batani, et al.: New J. Phys. 17 (2015) 083051.

56) P. Korneev, E. D’ Humieres, and V. Tikhonchuk: Phys. Rev. E 91 (2015) 043107.

57) S. V. Bulanov, T. Z. Esirkepov, M. Kando, J. Koga, K. Kondo, and G. Korn: Plasma Phys. Rep. 41 (2015) 1. 